\title{
Farmers' Intention to Leave the Agricultural Sector in East Java, Indonesia: A Crisis Through Non Agricultural Job Opportunities Challenges
}

\author{
Nuriah yuliati ${ }^{1}$, kusnandar ${ }^{2}$ Teguh soedarto $^{3}$ Endang siti rahayu ${ }^{2}$
}

${ }^{1}$ Doctoral Programs of Agricultural Science, Graduate School of Sebelas Maret University, Departement of Agribusiness, Faculty of Agriculture, University of Pembangunan Nasional "Veteran" East Java, Indonesia

${ }^{2}$ Departement of Agriculture Science, Graduate School of Sebelas Maret University, Central Java, Indonesia

${ }^{3}$ Departement of Agribusiness, Faculty of Agriculture, University of Pembangunan Nasional "Veteran" East Java, Indonesia

nuriah_y@upnjatim.ac.id

\begin{abstract}
Farmers' intention to leave the agricultural sector is a crucial reasoned action for the future of the Indonesian agricultural sector. The aims of research are described the type of livelihood that sustains the farm household's economy, and analyze the influence of Job Opportunities toward Farmer's Intentions Leaving the Agriculture Sector. The sampling was done by multistage sampling so that 360 households of paddy farmers were obtained in six villages, Bangil sub-district, Pasuruan Regency, Province of East Java. Data analysis using descriptive statistics and Structural Equation Modelling (SEM) PLS analysis with Warp PLS software. The findings of the study indicate that the relatively large number of non-agricultural jobs carried out by the household labor of farmers, most of them are trade and factory employees. The best job opportunity is in line with farmers' favorite choice for non-agricultural livelihoods. Employment opportunities have a positive and significant impact on farmers' intention to leave the agricultural sector.
\end{abstract}

Keywords: Employment Opportunities, Farmers' Intentions Leaving the Agricultural Sector, Farmer Household

\section{Introduction}

The progressive development of agricultural growth in the world cannot be separated from the successful transformation of the economy. The change is meant not only in technology, economic and social institutions, but also its workforce (Todaro and Stephen, 2011) through the construction of thinking the perpetrators. The agricultural sector is the application of reason and human works through the control of the biological processes of plants and animals, making it more useful for human life. This characteristic arises because agriculture involves a living thing in one or several stages and requires space for that activity as well as a certain period of time in the production process. In fact, many developing countries have large agricultural areas but cannot take advantage of the excess farmland they own. Like the economic growth in Indonesia, not yet accompanied by changes in the structure of a balanced labor force. Generally, the people of Indonesia entered in the argumentation of western theorists that who buzzed how to build and promote the economy of a nation that is by turning the agrarian economy into an industrial economy. Todaro and Stephen (2011), state that the impact of the transition process is the high migration rates of villagers to urban areas that are actually too densely populated for the inhabitants while the agricultural land in the village is abandoned. Ironically, no future generations will manage because young villagers and youth choose to migrate to cities to work in offices or in other industrial sectors in the hope of better living standards.

The Central Bureau of Statistics of Indonesia (2013) reported East Java as a major contributor to Indonesian agriculture where the number of agricultural business households in 2013 was 4.98 million households consisting of food crops sub sector of 3.67 million households, horticulture 2.22 million households, 1.58 million households for plantation sub sector, 3.34 million households of husbandary, 0.19 million households for fishery and 1.45 million households for forestry sub sector, fell 1.14 million households, a decrease of 23.25 percent 
compared to year 2003. The decline in the number of agricultural households, likewise the main employment of the agricultural sector, and otherwise the increase in non-agricultural sector employment in Indonesia is defined as an indication of the economic transformation of farm households. The transformation of farmers to nonagricultural employment is viewed positively to the extent that it does not have a negative impact such as decreasing the welfare of farmers or abandoned agricultural sectors due to lack of managerial resources (Dedehouanou et al., 2018 and Wang et al., 2017).

The intention of farmers to leave the agricultural sector needs to be studied scientifically for inputs of agricultural development policy so as not to develop crucially. If farmers leave the agricultural sector without control, then it can threaten the existence of agriculture as a producer of food and human primary needs. A number of empirical studies have been found with the topic of the intention of leaving the job especially in the field of organizational management (Abelson, 1987, Barnes et al., 1998; Blaauw et al., 2013; Brahmasari and Mujanah, 2017; Fakunmoju et al., 2010; Friedman, 2007, Hussein et al., 2014; Nasir, 2016; Opeyemi, 2013; and Simo et al., 2010), as well as the focus of study intentions of leaving the work mostly related to employee job satisfaction and organizational commitment.

This study presents the freshly concept of theoretical in which the intention of leaving agriculture is correlated with the job opportunities of farmers to support the household economy, as it is known that research reveals it is still very limited in agriculture Rothmann et al., (2013); Zhao et al., (2017) and Zhongwei and Xiaofeng (2012). Indonesian farmers in the perspective of dualistic economic theory Boeke (Kuhnen, 1987; Ranis, 2003) deals with traditional and modern economic structures as well as technology, social, cultural and regional. Traditional subsistence sector employment opportunities consist of small-scale agriculture, handicrafts and small trades, have high levels of labor intensity but low capital intensity and little division of labor. The employment opportunities of the modern sector of capital-intensive and plantation-oriented agricultural industries are world markets with capital-intensive production methods with high division of labor. Such dualistic economic conditions can be a stimulus for farmers to work double, ie agriculture and non-agriculture or intention to leave in agricultural sector. This research proposes a research question that can the intention of leaving the agricultural sector is formed from the perspective of job opportunities in farm households, and how mechanisms occur in household farming economies.

\section{Literature Review}

\section{Farmers' Job Opportunities}

Job opportunities are labor forces that have the opportunity to work in an economy (Esmara, 1986); (Rees, 1957); and (Sagir, 1989). The concept of employment is related to a broader concept, namely employment that includes the population, the labor force, not the labor force, and unemployment. Lewis (1954) states that a country's economy consists of traditional economies and industrial economies, as occurs in developing countries such as Indonesia, the Philippines or the North Caucasus (Briones, 2013; and Mamedov et al., 2016). Differences in industrial and agricultural wages increase the attractiveness of rural communities to urbanize. Due to differences in wages in both sectors, labor of agriculture sector moved to urban industrial sector (Ranis, 2003).

\section{Farmers' Intentions Leaving the Agricultural Sector}

Kaur and Pankaj (2013) defines intentions as statements about the specific behavior desired. The intention of leaving the organization (turnover intention or intention to leave) has been recognized as the best predictor of actual behavior. The intention of the employee to resign permanently, voluntarily or not from an organization is known as the concept of intention to leave (Robbins and Judge, 2006). High levels of intention to leave interfere with the efficiency of the organization. Similarly, by analogy when quality farmers leave agriculture excessively then the existence of agriculture is disrupted. Abelson (1987) defines intention to leave as someone's desire to move on and look for alternative workplaces. This action consists of several components such as the intention to exit, the desire to find another job, evaluate the possibility to find decent work elsewhere, and the desire to leave an organization. The intention to leave is only fixated on the employee's tendency to leave his 
organization now where the concept is often misunderstood with the concept of employee turnover (Singh and Singla, 2014). According to (Jaros et al., 1993) intentionion to leave is the beginning of turnover behavior that directly reflects a combination of outgoing attitudes of the organization. According to Abelson (1987) there are 3 indicators of intention to leave the organization, namely: (1) Think about quitting; (2) Conviction decision to quit; and (3) Perceived chance of leaving. The intention to leave intention or leave theory as described above becomes the basic indicator of farmers' abandonment of agriculture, leaving because it is unsatisfactory, for some reason, or because there are other options more interesting. Khan et al. (2014) explains that intentionion to leave is a negative perception of the employee to which job has the potential to leave the organization if employees feel discomfort and exhaustion at work. Intentionion to leave refers to the tendency of employees to cease to be part of membership in the organization.

\section{Materials and Methods}

\section{Sites}

The location of the study was in the region with the condition of the number of farm households decreasing, while the number of non-farm households increased. This condition indicates the opening of employment opportunities. Based on empirical data selected 6 villages namely Kolursari, Dermo, Kalirejo, Masangan, Manaruwi and Tambakan, Bangil District, Pasuruan Province, East Java Province, Indonesia. Site selection with consideration in the village many rice farmers who have double jobs (agriculture and non-agricultural). The sample size of each village is 60 Household Farmers so that the overall sample of 360 Farmers' Households is taken from the population using multistage sampling.

\section{Data Analyzed}

Descriptive statistical analysis (Supranto, 2007), was used to analyze data of livelihoods that sustained the household economics of farmers and the best employment opportunities for household farming economies. Analysis of SEM PLS (Partial Least Square) with Warp PLS version 5 software, including model measurement (outer model), model structure (inner model) and hypothesis testing (Ghozali, 2008) is used to analyze farmers' intention to leave agriculture sector.

\section{Relationship between Variables}

The relationship between the variables that affect (job opportunity) and the variables that are affected (farmers' intention to leave the agricultural sector) is formed on latent variables. The forming indicators are formative indicators for job opportunity variables and reflective indicators for variables of farmers' intention to leave the agricultural sector. Lewis (1954) describes the relationship between the quantity of labor, wages and production in the agricultural sector. Differences in wages in the agricultural and industrial sectors add to the attractiveness of rural communities to urbanize to enter the industrial sector. Therefore, in this study wages in the agricultural sector (X4), working hours in the agricultural sector (X5), wages in non-agricultural sector (X6), and working hours in non-agricultural sector (X7) become indicators for employment variables. Other indicators, ie age (X1), education (X2), number of family members (X3), are the characteristics of farmers. Griffin et al., (1981) states that the similarities and differences in organizational characteristics of employees such as age, gender, ethnicity, inheritance, physical abilities and disabilities, race and sexual orientation are essentially related to labor diversity. Therefore, the characteristics of farmers including age, education, and the number of family members in this study also become an indicator for the employment variables.

Variable intentions of farmers to leave the agricultural sector were approached with an indicator of job satisfaction $(\mathrm{Y} 1)$, moved with a certain cause $(\mathrm{Y} 2)$, and moved because of other options $(\mathrm{Y} 3)$. The determination of these indicators is based on Abelson's (1987) explanation of the factors that influence employees' intention to leave the organization. 


\section{Results and Discussion}

\section{Livelihood of Farmer's Household}

The types of livelihoods of farm households in non-agricultural sectors are relatively diverse. Table 1 shows that $45.00 \%$ of household heads and $24.61 \%$ non-family heads work as traders, while $30.28 \%$ and $53.13 \%$ are factory employees. The phenomenon, parents mostly work as a merchant instead of children mostly work as factory employees. Some work in the food and beverage industry, shoe companies, canned fish, light bulbs, furniture, and toothpaste. There is also a trader with tofu and tempe, clothing store, small trader, selling in the market, meatballs, chicken pieces, sate, street vendors, and even food stalls. The behavior of parents and children in choosing the type of work is (Table 1) such as the head of the farmer's household (the parents) prefer to be a trader, while the farmer's children prefer to become factory employees. Peasant children tend to avoid jobs that require more physical strength such as construction and transport services, besides that farmers tend to choose the type of work that looks prestigious like tailor and rental's events. An exciting phenomenon as an indication of the progress of development outcomes in the field of education is the existence of child farmers who work as doctors; and the phenomenon is not encouraging is the child farmers tend to leave the agricultural sector. The phenomenon of child farmers tends to leave the agricultural sector in line with the findings of Agwu et al. (2014) research in the states of Abia, the Federal Republic of Nigeria and Grubbström and Sooväli-Sepping, (2012) in Estonia. Zentner et al. (2005) found that in the United States and Canada 66\% of parents did not allow their children to work in the agricultural sector.

\section{Job Opportunities}

The best employment opportunities for farm households are reflected by the livelihoods absorption (Table 1.)

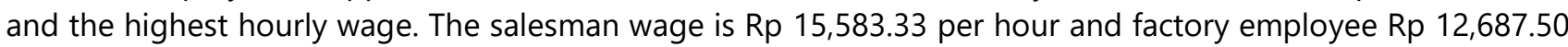
per hour is the best job opportunity in the research area. There seems to be a correlation between the favorability of livelihood and the rate of wage labor. Traders and factory employees as a favorite livelihood for heads of households and household members have a relatively high wage compared to non-favored livelihoods and other livelihoods. In other words, the high rate of wages becomes "invisible hand" for the labor force to choose the type of work or livelihood that argued Smith in year 1776. This phenomenon conforms to the findings of Herrendorf and Schoellman (2017) that the average wage of non-agricultural is much greater than the average wage in agriculture. The farmers' and your factory's favorite livelihood wage rates are approximately twice that of non-favorite livelihoods such as motor garage and transportation.

Table 1. Livelihood Type of Farmer's Household

\begin{tabular}{llcccc}
\hline No. & Livelihood & \multicolumn{2}{c}{ Householder } & \multicolumn{2}{c}{ Non-Householder } \\
\cline { 3 - 6 } & & $\begin{array}{c}\text { Amount } \\
\text { (Soul) }\end{array}$ & $\begin{array}{c}\text { Percentage } \\
\text { (\%) }\end{array}$ & $\begin{array}{c}\text { Amount } \\
\text { (Soul) }\end{array}$ & $\begin{array}{c}\text { Percentage } \\
\text { (\%) }\end{array}$ \\
\hline A & Agricultural & & & 0 & 0,00 \\
\hline 1. & Paddy & 360 & 100,00 & 0 & 0,00 \\
\hline 2. & Watermelon & 19 & 5,28 & 0 & 0,00 \\
\hline & Cantaloupe & 6 & 1,67 & & \\
\hline B & Non-Agricultural & & & 63 & 24,61 \\
\hline 1. & Salesman & 162 & 45,00 & & \\
\hline
\end{tabular}




\begin{tabular}{clcccc}
\hline 2. & Employee & 109 & 30,28 & 136 & 53,13 \\
\hline 3. & Construction & 38 & 10,56 & 3 & 1,17 \\
\hline 4. & Transport Services & 20 & 5,56 & 4 & 1,57 \\
\hline 5. & Government & 9 & 2,50 & 16 & 6,25 \\
\hline 6. & Broker & 9 & 2,50 & 0 & 0,00 \\
\hline 7. & Security & 4 & 1,11 & 6 & 2,34 \\
\hline 8. & Tailor & 4 & 1,11 & 21 & 8,20 \\
\hline 9. & Metal Craftsmen & 3 & 0,83 & 1 & 0,39 \\
\hline 10. & Rental Events & 2 & 0,55 & 0 & 0,00 \\
\hline 11. & Motor Garage & 0 & 0,00 & 4 & 1,56 \\
\hline 12. & Doctor & 0 & 0,00 & 2 & 0,78
\end{tabular}

Source: Data Analyzed (2017)

\section{Structural Equation Model of Farmer's Intentions Leaving the Agricultural Sector}

\section{Model Fit Evaluation}

The outer model shows the relationship of latent variables with their indicators. Solimun et al. (2017) explains that latent variables with formative indicator models are formed from indicators whose data are quantitative. Kock (2015), states that the fit and quality indices model is useful for managing related steps for the quality model in hypothesis testing. The result showed that Average Path Coefficient (APC) $=0,281$, Average R-Squared $(A R S)=0,279$ and AARS $=0,363$ have fulfilled requirement of fit model that is value $\leq 0.05$. Niilai $A V I F=3,815$ and $\mathrm{AFVIF}=3,505$ means to enter in acceptable value category, hence it is concluded that in this research model does not occur multicollinearity. The value of $\mathrm{GoF}=0.482$, entered in a large value category, so the higher the GoF value, the better a research model (Kock, 2015). SPR value $=1$, meaning that in the model there is no Paradox Simpson. The value of RSCR $=1$ means no $R$ Squared negative contribution. SSR value $=1$ means a free model of statistical suppression. The value of NLBCDR $=1$ means the variable supports the hypothesis in the model. In conclusion, all ten criteria are shown that the model in this study fulfill the requirements of the fit model.

The strongest formative indicator is the wage indicator in the non-agricultural sector (X6) with a value of 0.696 as the form of the employment variable, the indicator of the number of family members, working hours in agriculture, wages in agriculture, working hours in the non-agricultural sector and education. The age indicator of the value of -0.239 means that the negative direction due to the $p$ value $<0.05$ and the VIF value $<5$, it means there is no multicollinearity then all the indicators are valid (Kock, 2015).

Test outer models with reflective indicators, including Convergent Validity, Discriminant Validity, Average Variance Extracted (AVE), Cronbach Alpha and Composite Reliability. According to Ghozali and Latan, (2015) the value of convergent validity is the value of loading factor on latent variables with the indicators. The loading factor is greater 0.7 and the significance of all indicators $(p)$ is less than 0.001 then all reflective latent indicators (Table 2.) meet convergent validity. In the outer reflective model, the discriminant validity criterion is to compare the loading value of each indicator greater than the value of its cross loading. The loading factor of job 
satisfaction (0.724), loading factor moved with certain cause (0.772), and loading factor moved due to certain options (0.742), all greater than the value of cross loading so that all conclude the discriminant validity.

The construct is said to have good reliability if the AVE Value is above 0.50, Cronbach's Alpha is met if it is greater than 0.60 while the composite reability is met if it is larger than 0.70 (Shandyastini and Novianti, 2016). Variables of employment opportunity and intention of farmers leaving the agricultural sector have met the reliability requirements. AVE values above 0.50 (0.603 and 0.689), Cronbach alpha values above 0.6 (0.708 and $0.779)$ and composite reliability values above 0.7 (0.734 and 0.858$)$.

Model Testing

The structural model (inner model) is a structural model to predict the causality relationship between latent variables. Inner model testing is done to see the relationship between constructs, and R square of the model (Abdillah and Jogiyanto, 2015). The effect of employment on farmers 'intention to leave the agricultural sector with R-squared of 0.57 indicates that farmers' intention to leave the agricultural sector is influenced by job opportunity by $57 \%$, while the remaining $43 \%$ is influenced by factors not found in the model.

Path coefficient of 0.281 indicates that the magnitude of the effect of employment opportunities on farmers' intention to leave the agricultural sector is 0.281 and $P$ value $=0.010$. Thus, the working hypothesis of research which states that the employment of farm households influences the farmer's intention to leave the agricultural sector, is accepted (Table 3.).

Table 2. Construction Reliability

\begin{tabular}{lccc}
\hline \multicolumn{1}{c}{ Variabel } & $\begin{array}{c}\text { Average Variances } \\
\text { Extracted (AVE) }\end{array}$ & $\begin{array}{c}\text { Cronbach's } \\
\text { Alpha }\end{array}$ & $\begin{array}{c}\text { Composite } \\
\text { Reliability }\end{array}$ \\
\hline Job Opportunity $(\mathrm{X})$ & 0,603 & 0,708 & 0,734 \\
\hline $\begin{array}{l}\text { Farmers' Intentions Leaving the } \\
\text { Agricultural Sector }(\mathrm{Y})\end{array}$ & 0,689 & 0,779 & 0,858 \\
\hline
\end{tabular}

Source: Result by WarpPLS 5.0 (2017).

Tabel 3. Testing Model of Influence among Variables

\begin{tabular}{|c|c|c|c|c|}
\hline & Research Hypothesis & Path Coefficient & P-value & Keterangan \\
\hline $\begin{array}{l}\text { Job } \\
\text { Inter }\end{array}$ & $\begin{array}{l}\text { Opportunity } \rightarrow \text { Farmers' } \\
\text { ttions Leaving the Agricultural }\end{array}$ & $0,281^{* * *}$ & 0,010 & $\begin{array}{c}\text { Sangat } \\
\text { Significant }\end{array}$ \\
\hline
\end{tabular}

Sector

Explanation : * $\alpha \leq 0,10^{* *} \alpha \leq 0,05 ;{ }^{* * *} \alpha \leq 0,01$

Source: Result by WarpPLS 5.0 (2017). 


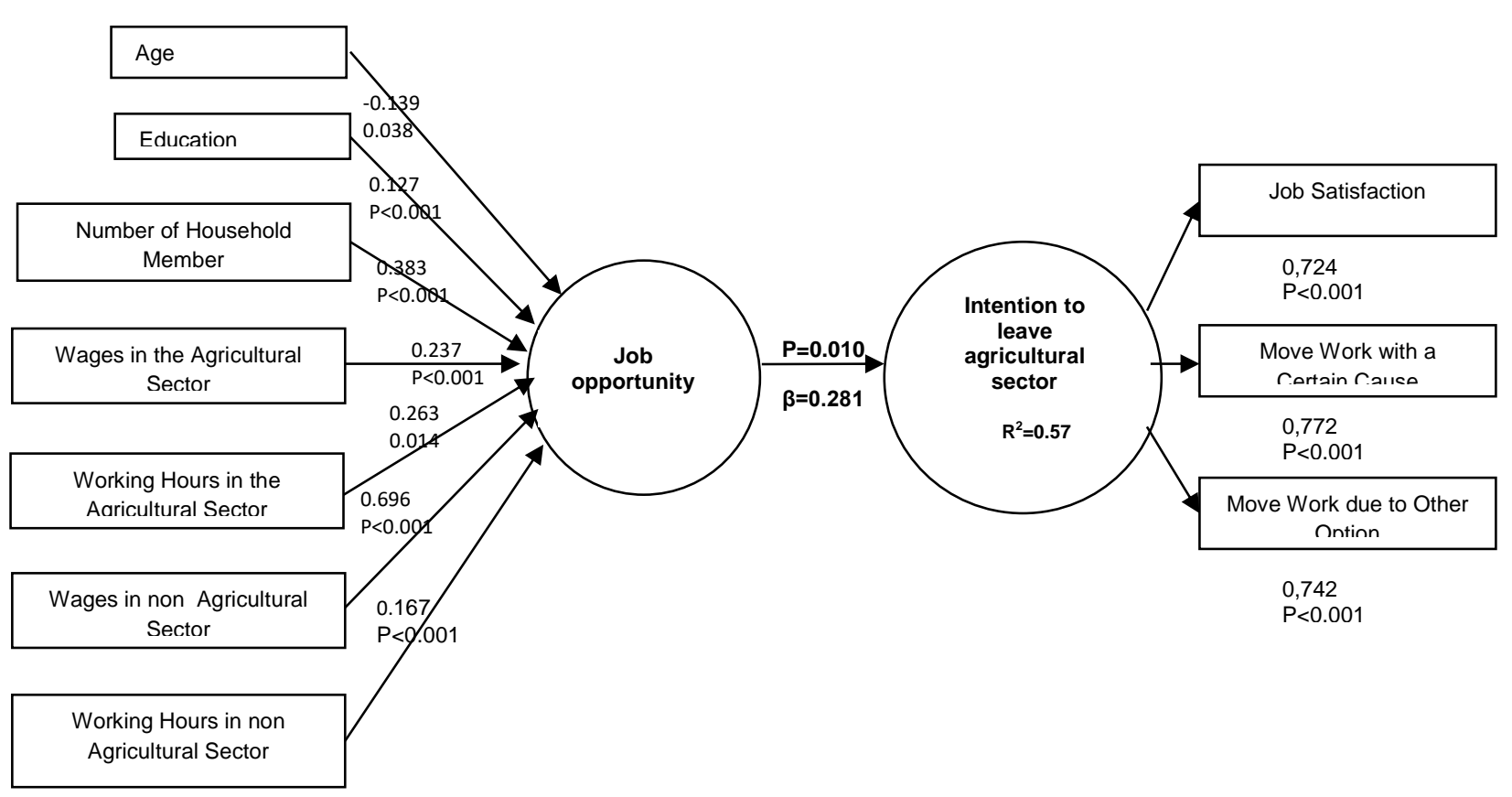

Figure 1. Influence of Construct Diagram by WarpPLS.

Based on Figure 1. job opportunities have a positive and significant impact on farmers' intention to leave the agricultural sector. This is indicated by the 0.281 coefficient path and significance with P-value $=0.010$ (Table 3). The wider job opportunities in the non-agricultural sector further encourage farmers' intention to leave the agricultural sector. When farmers think of leaving the agricultural sector, they will be busy looking for nonagricultural employment opportunities and actively looking for them. This is in accordance with research findings (Deichmann et al., 2009) in Bangladesh ie farmers with job opportunities (close to cities) will be increasingly encouraged to work in non-agricultural sectors.

The determination of farm households to realize their intention to leave or remain in the agricultural sector seems to be determined by the level of adequacy of household economic needs. That is why farmers are looking for a double livelihood to meet their needs. It appears in Table 1. that wages in the non-agricultural sector (X6) are the highest-weighted (0.696) indicator in forming / supporting the employment variables. It means, job opportunities in non-agricultural livelihoods are considered important or less important for a farm household depending on the high-low wage rates. The high level of non-agricultural livelihood wages indicates the importance of the livelihood role to the fulfillment of farmers' household needs. The findings of this study are consistent with the findings of Agwu et al. (2014) research in the Nigerian state of Abia also indicating that nonfarm income negatively affects the participation of youth working in the agricultural sector. That is, the increase in non-agricultural income followed by the tendency of reduced youth participation in agricultural work. Tocco et al., (2013) studied in the European Union (France, Hungary, Italy, Poland and Slovakia) on the determinants of move out agriculture, suggesting that youth are more likely to leave agriculture, although the greatest flows leave agriculture associated with old age. Self-employed and family workers generally also tend to leave his farm life.

\section{Conclusion}

1. Employment opportunities of farm households in non-agricultural sectors are relatively diverse, ie 12 types of livelihood. The head of the household chooses as a merchant, while the farmer selects more as a factory employee. The unfortunate phenomenon is the abandonment of agricultural employment opportunities by the peasant children. 
2. The best employment opportunities for farm households seem to correlate with farmers' preferred choices for non-agricultural livelihoods, ie traders and factory employees. The high level of wages becomes "invisible hand" for the work force to choose the preferred type of livelihood. Statistically, the wage weight indicator in the non-agricultural sector of 0.696 is the highest score of 7 indicators for the employment variable in the outer formative model.

3. Employment opportunities have a positive and significant impact on farmers' intention to leave the agricultural sector. Employment opportunities and the intention of leaving it seem to be based on consideration of the role of livelihoods to the economic needs of farm households. Statistically, all factors loading indicator intention of leaving the agricultural sector is worth higher than the value of its cross loading. Nevertheless, the loading factor moved with the highest certain cause (0.772) than the loading factor moved by a certain choice $(0.742)$ and the job satisfaction loading factor $(0.724)$. At least the numerical difference in factor loading values of these three indicators indicates that the value of job satisfaction and relocation due to certain options in non-agricultural employment is not a dominant indicator for the intention of leaving the agricultural sector. This phenomenon is different from the findings of research in the field of organization or manufacturing which generally indicates that job satisfaction is a decisive factor leaving the organization. So further research needs to be proved by similar cases in different areas

\section{Data Availability}

The data may be accessed by contacting author's email in nuriah_y@upnjatim.ac.id. The data are in both excel and sav format.

\section{Conflicts of Interest}

The authors declare that there are no conflicts of interest in the submission of this article for publication.

\section{References}

1. Abelson, M., 1987. Examination of Avoidable and Unavoidable Turnover. J. Appl. Psychol. 72, 382-386.

2. Abdillah, W., and Jogiyanto. 2015. Partial Least Sq. PLS Altern. Struct. Equ. Model. SEM within Business Research. CV Andi Offset. Yogyakarta.

3. Agwu, N.M., Nwankwo, E.E., Anyanwu, C.I., 2014. Determinants of agricultural labour participation among youths in Abia State, Nigeria. Int. J. Food Agric. Econ. 2, 157.

4. Barnes, L.L., Agago, M.O., Coombs, W.T., 1998. Effects of Job-Related Stress on Faculty Intention to Leave Academia. Res. High. Educ. 4, 457-469.

5. Blaauw, D., Ditlopo, P., Maseko, F., Chirwa, M., Mwisongo, A., Bidwell, P., Thomas, S., Normand, C., 2013. Comparing the job satisfaction and intention to leave of different categories of health workers in Tanzania, Malawi, and South Africa. Glob. Health Action 6, 19287. https://doi.org/10.3402/gha.v6i0.19287

6. Brahmasari, H., Mujanah, H., 2017. The Effect of Individual Characteristics, Competence and Quality of Work Life On Work Motivation, Intention to Leave and Employee Performance Outsoursing Manufacturing Company in East Java Province. Arch. Bus. Res. 5.

7. Briones, R.M., 2013. Agriculture, rural employment, and inclusive growth. PIDS Discussion Paper Series.

8. Dedehouanou, S.F.A., Araar, A., Ousseini, A., Harouna, A.L., Jabir, M., 2018. Spillovers from off-farm selfemployment opportunities in rural Niger. World Dev. 
9. Deichmann, U., Shilpi, F., Vakis, R., 2009. Urban Proximity, Agricultural Potential and Rural Non-farm Employment: Evidence from Bangladesh. World Dev. 37, 645-660. https://doi.org/10.1016/j.worlddev.2008.08.008

10. Esmara, H., 1986. Human Resources, Job Opportunity and Economic Development.

11. Fakunmoju, S., Woodruff, K., Kim, H.H., LeFevre, A., Hong, M., 2010. Intention to Leave a Job: The Role of Individual Factors, Job Tension, and Supervisory Support. Adm. Soc. Work 34, 313-328. https://doi.org/10.1080/03643107.2010.500948

12. Friedman, B.A., 2007. Union Membership: Facet Satisfaction, and Intent to Leave: Further Evidence on the Voice Face of Unions. LERA Libr.

13. Ghozali, I., 2008. Structural equation modeling: Alternative Methods with Partial Least Square (PLS). Universitity of Diponegoro Press. Semarang. Indonesia.

14. Ghozali, I., Latan, H., 2015. Partial Least Squares, Concepts, Techniques and Applications Using Smartpls 3.0 Program for Empirical Research. Universitity of Diponegoro Press. Semarang. Indonesia.

15. Grubbström, A., Sooväli-Sepping, H., 2012. Estonian family farms in transition: a study of intangible assets and gender issues in generational succession. J. Hist. Geogr. 38, 329-339. https://doi.org/10.1016/j.jhg.2012.03.001

16. Halawi, A.H., 2014. Stimuli and effect of the intention to leave the organization. Eur. Sci. J. 10.

17. Hellman, C.M., 1997. Job Satisfaction and Intent to Leave. J. Soc. Psychol. 137, 677-689. https://doi.org/10.1080/00224549709595491

18. Herrendorf, B., Schoellman, T., 2017. Wages, human capital, and structural transformation.

19. Hussein, S., Moriarty, J., Stevens, M., Sharpe, E., Manthorpe, J., 2014. Organisational factors, job satisfaction and intention to leave among newly qualified social workers in England. Soc. Work Educ. 33, 381-396.

20. Jaros, S., Jermier, J., W. Koehler, J., Sincich, T., 1993. Effects of Continuance, Affective, and Moral Commitment on the Withdraw Process: An Evaluation of Eight Structural Equation Models. Acad. Manage. J. 36, 951-995.

21. Kaur, B., Pankaj, M., 2013. Antecedents of turnover intentions: A literature review. Glob. J. Manag. Bus. Stud. 3, 1219-1230.

22. Khan, M.S., Khan, I., Kundi, G.M., Khan, S., Nawaz, A., Khan, F., Yar, N.B., 2014. The Impact of Job Satisfaction and Organizational commitment on the Intention to leave among the Academicians. Int. J. Acad. Res. Bus. Soc. Sci. 4, 114.

23. Kock, N., 2015. WarpPLS 5.0 User Manual. 2015. Laredo TX ScriptWarp Syst.

24. Lewis, W.A., 1954. Economic development with unlimited supplies of labour. Manch. Sch. 22, 139-191.

25. Mamedov, O., Movchan, I., Ishchenko-Padukova, O., Grabowska, M., 2016. Traditional economy: innovations, efficiency and globalization. Econ. Sociol. 9, 61.

26. Nasir, N.F.B.M., Author, D.I.B.S., n.d. The Role of HRM Practices in Influencing Employees' Intention to Leave. 
27. Opeyemi, B.E., 2013. Identifying the Effect of Job Stress on Frontline Staffs' Job Burnout, Job Engagement, Job Satisfaction and Intention to Leave: An Empirical Study in Nigeria.

28. Ranis, G., 2003. Is Dualism Worth Revisiting? Yale University, Economic Growth Center. Discussion Paper.

29. Rees, A., 1957. The Meaning and Measurement of Full Employment, in: The Measurement and Behavior of Unemployment. NBER, pp. 11-62.

30. Robbins, S.P., Judge, T.A., 2006. Organizational behavior. Tenth Edition. PT Indeks Kelompok Gramedia.

31. Rothmann, S., Diedericks, E., Swart, J.P., 2013. Manager relations, psychological need satisfaction and intention to leave in the agricultural sector. SA J. Ind. Psychol. 39, 01-11.

32. Sagir, S., 1989. Building human works: manpower issues and human resource development. Pustaka Sinar Harapan.

33. Simo, P., Enache, M., Sallan, J., Fernandez, V., 2010. Analysis of the relation between subjective career success, organizational commitment and the intention to leave the organization.

34. Singh, D., Singla, R., 2014. Factors Determining Employees Intent to Leave an Organization: A View from Private Education Industry with Special Reference to Professional Institutions in Patiala.

35. Smith, A., 1776. An Inquiry into the Nature and Causes of the Wealth of Nations, Methuen.

36. Solimun, Fernandes, A., Nurjannah, N., 2017. Multivariate Statistical Method: Structural Equation Modeling Based on WarpPLS.

37. Supranto, J., 2007. Statistics for the Leader of Global Insight (ed 2). Salemba Press.

38. Tocco, B., Bailey, A., Davidova, S., 2013. Determinants to leave agriculture and change occupational sector: Evidence from an enlarged EU. International Agricultural Trade Research Consortium.

39. Todaro, Michael P. and Smith, Stephen C. 2011. Economic Development. Eleventh Edition. United States: Addison Wesley.

40. Wang, X., Huang, J., Rozelle, S., 2017. Off-farm employment and agricultural specialization in China. China Econ. Rev. 42, 155-165. https://doi.org/10.1016/j.chieco.2016.09.004

41. Zentner, J., Berg, R.L., Pickett, W., Marlenga, B., 2005. Do parents' perceptions of risks protect children engaged in farm work? Prev. Med. 40, 860-866. https://doi.org/10.1016/j.ypmed.2004.10.007

42. Zhao, X., Deng, S., Zhou, Y., 2017. The impact of reference effects on online purchase intention of agricultural products: The moderating role of consumers' food safety consciousness. Internet Res. 27, 233-255. https://doi.org/10.1108/IntR-03-2016-0082

43. Zhongwei, S., Xiaofeng, Y., 2012. Disembedded Employment Relationship and Turnover Intention of Peasant-Workers. Based on a Survey of Peasant-Workers in the Yangtze River Delta and Pearl River Delta. Soc. Chin. J. Sociol. 32. 